\title{
The Applicability of Renewable Raw Materials for the Professional Horticulture-Ecosystem Services, Profitability and Refinement
}

\author{
Simon Grießer \\ Chair of Landscape Ecology, University of Vechta, Vechta, Germany \\ Email: simon.griesser@mail.uni-vechta.de, s.griesser@gramoflor.de \\ Received 24 April 2015; accepted 21 May 2015; published 22 May 2015 \\ Copyright (C) 2015 by authors and Scientific Research Publishing Inc. \\ This work is licensed under the Creative Commons Attribution International License (CC BY). \\ http://creativecommons.org/licenses/by/4.0/

(c) (i) Open Access

\begin{abstract}
This preliminary study shows an innovative concept of searching for peat substitutes on basis of renewable raw materials considering the cultivation in extensive land use in Lower Saxony (Germany). Selecting suitable raw material plants against the background of ecological, social and economic issues followed by testing series including those materials should lead on to reliable results for a planned transition through a spatial analysis of potential areas for cultivation with a specific attention on wetlands. Thereby this short report illustrates the concept of the study as well as chosen interim results and it is to be understood as the first paper of a mini-series.
\end{abstract}

\section{Keywords}

Growing Media, Location Suited and Extensive Land Use, Lower Saxony, Germany, Prospects for Farmers and Horticulturists

\section{Introduction}

Reproductive soil is essential. The genesis of $10 \mathrm{~cm}$ of soil takes about 2000 years. Through the present, mostly intensive and yield optimized way of land use, erosion and greenhouse gas emission is resulting. Therefore the protection of soil must be an ecological, social and economic issue [1]. However, it is obvious that the increasing global population and interconnectedness is leading to an intensification of agricultural production. In the past decades this development led to a high level of standardization in professional horticultural production whereby peat could enforce because of its dependability concerning the crucial parameters for successful culti- 
vation of vegetables and plants [2] [3]. Attributes of peat like low bulk density, high porosity, low pH, nutrient and nitrogen immobilization and structural stability, enable horticulturists a controlled and solid adjustment of professional gardening [4]. Drainage based agriculture and subsequent peat mining over the last few decades led to degradation of wetlands in Lower Saxony (Germany). In this regard the federal government and the government of Lower Saxony strive for a reduction of peat in horticultural production [5]-[7]. Furthermore there is a lack of peat substitutes in both qualitative and quantitative perspectives. About 9 million $\mathrm{m}^{3}$ substrates for horticultural usage are annual needed in Germany whereof none but about $10 \%$ native and renewable raw materials with qualitative applicability would be obtainable [8] [9].

The research gap identified in this study is the testing of extensive land use options with high-fibre renewable raw materials for the usage as substrate for professional horticulture. Thereby we conduct horticultural tests with selected high-fibre raw material plants and search for pertinent locations of raw material plants on both mineral and organic soils in rural areas of Lower Saxony (Germany). Especially the search for pertinent locations on bog edges is focused to contribute to a sustainable agriculture.

\section{Structure and Methods of the Study}

The study began in September 2014 with a literature review about the relevant state of research with a special focus on suitable raw material plants. That part will be followed by a horticultural testing series with the chosen raw material plants in different refinements, cultures and admixture rates. Conclusively, the study will identify appropriate areas in Lower Saxony (Germany) for extensive production of renewable raw materials for the professional horticulture.

Meanwhile the first part of the study was completed. In this matter we comprehensive studied the relevant literature concerning the selection of the renewable raw materials. To find an economic attractive way for the admixtion of raw material plants in peat based substrates composting was dropped out as an option of refinement because of its deficiency of storability, its volume depletion and its high weight. Constructing on this reflection we searched for plants with high-fibre rates, high lignin rates to get an increment of volume and high harvest revenue in due consideration of its none invasiveness and its possibility to cultivate in extensive ways on pertinent locations.

The upcoming step is to refine the chopped material through an applications laboratory. This laboratory will refine the material in three ways: shred, curb and shred and defiber including the conveyance of nitrogen and coaldust. The last refinement is the most sophisticating and promising one.

The refined materials will be admixed for the test series by volume of $15 \%, 30 \%$ and $45 \%$ additional to a standardized peat based substrate. Tests will be enforced with several cultures in multiple replicas to get convincing results about the selected raw material plants and the chosen ways of refinement.

Parallel to the ongoing public relations activities with the aid of exhibition parcel land, the last part of the study is characterized by a spatial analysis of potential croplands in Lower Saxony (Germany).

\section{Interim Results of the Study}

At that point we have worked out interim results concerning the selection of the renewable raw materials and their refinement ways having regard to storability, lignin concentration, fibre rate, harvest revenue none invasiveness and cultivation options (Table 1). Moreover we have tested most of the selected raw material plants on existing cropland with the objective of getting information about volume weight, dry substance and revenue of a hectare per annum (Table 2).

\section{Conclusion, Discussion and Outlook}

The present paper shows the research design and several selected segments of the first part of the study. In the next step this study will search for answers about the qualitative utility of the testing materials as part of horticultural attempts. Furthermore a GIS-assisted analysis figures out where obtainable and suitable areas for cultivation within the territory of Lower Saxony (Germany) are.

The results given in Table 1 and Table 2 indicate economic options for a sustainable supply of raw materials for substrates for the professional horticulture. Otherwise we cannot make comparable statements about the missing materials of Table 2. In addition to it, we cannot make any statements about unverified raw material 
Table 1. Selected raw material plants and ways of refinement.

\begin{tabular}{cccc}
\hline Raw material plants (alphabetically) & Shred & Curb and shred & $\begin{array}{c}\text { Defiber including the conveyance } \\
\text { of nitrogen and coaldust }\end{array}$ \\
\hline Helianthus tuberosus (sunchoke) & $\mathrm{X}$ & $\mathrm{X}$ & $\mathrm{X}$ \\
Miscanthus $\mathrm{x}$ giganteus (giant Chinese silver grass) & $\mathrm{X}$ & $\mathrm{X}$ & $\mathrm{X}$ \\
Paulownia tomentosa (paulownia) & $\mathrm{X}$ & $\mathrm{X}$ & $\mathrm{X}$ \\
Phragmitesaustralis (reed) & $\mathrm{X}$ & $\mathrm{X}$ & $\mathrm{X}$ \\
Populus (poplar) & $\mathrm{X}$ & $\mathrm{X}$ & $\mathrm{X}$ \\
Salix (willow) & $\mathrm{X}$ & $\mathrm{X}$ & $\mathrm{X}$ \\
Sida (sida) & $\mathrm{X}$ & $\mathrm{X}$ & $\mathrm{X}$ \\
\hline
\end{tabular}

Table 2. Raw material characteristics.

\begin{tabular}{ccccccc}
\hline & $\begin{array}{c}\text { Volume } \\
\text { weight per } \\
\text { (EN) } \text { m }^{3} \text { in kg }\end{array}$ & $\begin{array}{c}\text { Dry } \\
\text { substance } \\
\text { in \% }\end{array}$ & $\begin{array}{c}\text { Net weight of each } \\
\text { pallet resp. per analyzed } \\
\text { raw material plant in kg }\end{array}$ & $\begin{array}{c}\text { Seedlings per ha- } \\
\text { obtained } \\
\text { from literature }\end{array}$ & $\begin{array}{c}\text { Planted } \\
\text { seedlings }\end{array}$ & $\begin{array}{c}\text { Rotation } \\
\text { in years } \\
\text { (crop intervals) }\end{array}$ \\
\hline $\begin{array}{c}\text { Giant Chinese } \\
\text { silver grass (recent) }\end{array}$ & 47 & 84.0 & 35.9 & 13,000 & 45 (rhizome) & 1 \\
$\begin{array}{c}\text { Poplar } \\
\text { (max 3 clone; recent) }\end{array}$ & 282 & 41.0 & 86.4 & 10,000 & 10 & 3 \\
$\begin{array}{c}\text { Poplar } \\
\text { (hybrid 275; recent) }\end{array}$ & 192 & 47.4 & 42.4 & 10,000 & 11 & 3 \\
$\begin{array}{c}\text { Willow } \\
\text { (tordis; recent) }\end{array}$ & 175 & 52.4 & 119.4 & 13,000 & 16 & 3 \\
$\begin{array}{c}\text { Sida } \\
\text { (recent) }\end{array}$ & 51 & 80.8 & 37.9 & $14,000(13,000-15,000)$ & 35 (rhizome) \\
$\begin{array}{c}\text { Cup plant } \\
\text { (recent) }\end{array}$ & 95 & 82.4 & 27.9 & 35,000 & 72 (rhizome) \\
\hline
\end{tabular}

plants that surely exist somewhere. Nevertheless it is necessary to contain the possibilities of the object of research to get a high quality of results.

The impending step is now the refinement of the selected raw material plants and the beginning of the horticultural testing series with the mixed substrate formula in different cultures. The horticultural tests will include experiments with Chinese cabbage as an indicator plant and afterwards we test the mixtures with shrub, decorative plants and vegetables to achieve outcomes about the suitability of mixtures, raw material plants and the ways of refinement.

\section{Acknowledgements}

The research project is facilitated by the Ministry of Food, Agriculture and Consumer Protection of Lower Saxony (Germany). The thereout arising dissertation is outstanding supported by the coauthors Prof. Dr. W. Schroeder and PD Dr. B. Breckling (both University of Vechta; Chair of Landscape Ecology).

\section{References}

[1] Chemnitz, C. and Weigelt, J. (2015) Bodenatlas. Daten und Fakten über Acker, Land und Erde. Institute for Advanced Sustainability Studies (IASS), Berlin, Potsdam.

[2] Altmann, M. (2008) Socio-Economic Impact of the Peat and Growing Media Industry on Horticulture in the EU. http://www.epagma.eu/sites/default/files/growing\%20media/socio_economic_study2008.pdf

[3] Alexander, P.D., Bragg, N.C., Meade, R., Padelopoulos, G. and Watts, O. (2008) Peat in Horticulture and Conservation: The UK Response to a Changing World. Mires and Peat, 3, 1-10. 
[4] Schmilewski, G. (2008) The Role of Peat in Assuring the Quality of Growing Media. Mires and Peat, 3, 1-8.

[5] Bundesministerium für Umwelt, Naturschutz und Reaktorsicherheit (2007) Nationale Strategie zur Biologischen Vielfalt. https://www.bfn.de/fileadmin/MDB/documents/themen/monitoring/biolog_vielfalt_strategie_nov07.pdf

[6] Niedersächsisches Ministerium für Ernährung, Landwirtschaft und Verbraucherschutz (2015) Torfersatzstoffe sollen helfen, Moore zu schützen.

http://www.ml.niedersachsen.de/portal/live.php?navigation_id=1810\&article_id=132521\&_psmand=7

[7] Niedersächsisches Ministerium für Umwelt, Energie und Klimaschutz (2005) Moorschutzprogramm. http://www.umwelt.niedersachsen.de/themen/natur_landschaft/fachprogramme/moorschutz/8207.html

[8] Gütegemeinschaft für Substrate für Pflanzen e.V. (2010)

https://www.giessen.de/PDF/Torf Ersatzstoffe $11 \quad 10$ Torffreie Landesgartensschau M\%C3\%B6glichkeiten und Gr enzen.PDF?ObjSvrID=1894\&ObjID=434\&ObjLa=1\&Ext=PDF\&WTR=1\&_ts=1429535222

[9] Industrieverband Garten e.V. (2009)

http://www.bund.net/fileadmin/bundnet/pdfs/naturschutz/moore2/20120405_naturschutz_moore_torf_fragen_und_ant worten_sonstiges.pdf 